\title{
Case of solitary plasmacytoma of tibia
}

\author{
Sandesh Madi, ${ }^{1}$ Vivek Pandey, ${ }^{1}$ Akhya Sharma, ${ }^{1}$ Vidya Monappa ${ }^{2}$
}

${ }^{1}$ Orthopaedics, Manipal Academy of Higher Education, Manipal, Karnataka, India ${ }^{2}$ Pathology, Manipal Academy of Higher Education, Manipal, Karnataka, India

\section{Correspondence to} Dr Sandesh Madi, sandesh.madi@gmail.com

Accepted 18 September 2018

\section{DESCRIPTION}

A 58-year-old diabetic man presented to the outpatient department with pain in his right leg of 6 months' duration. The pain was insidious in onset and gradually progressive. He was unable to bear weight on the affected side. On clinical examination, there was tenderness over the medial aspect of the upper part of the leg. The knee range of movements was limited and painful. The distal neurovascular examination was normal.

Plain X-ray of the knee (figure 1) showed an eccentric lytic lesion in the proximal end of the tibia with a pathological fracture of the medial wall. There was no periosteal reaction. Plain and contrast MRI study (figure 2) revealed a well-defined heterogeneously enhancing altered signal eccentric intramedullary lesion in the proximal metadiaphyseal region of the tibia with cortical breaks. The patient was taken up for open incisional biopsy, and prophylactic fixation of the proximal tibia was done using $4.5 \mathrm{~mm}$ proximal tibia lateral locking plate (figure 3). The histopathology features were suggestive of plasmacytoma (figure 4). The serology work-up for myeloma was performed (table 1 and figure 5). A skeletal survey did not yield any other lesions. The light chain analysis kappa was increased, and the Kappa/Lambda ratio was high, suggestive of monoclonal gammopathy. The patient is currently undergoing radiotherapy.

Plasmacytoma is a rare type of localised neoplastic plasma cell proliferation. Depending on the location, it is classified into solitary bone plasmacytoma (SBP) and extramedullary plasmacytoma. The median age for SBP is 55 years, and the common presentation of SBP is in the axial skeleton (vertebra, skull). ${ }^{1}$ The involvement of the distal appendicular skeleton beyond elbow or knee is rare. According to the authors' knowledge, there have been only two accounts of SBP reported

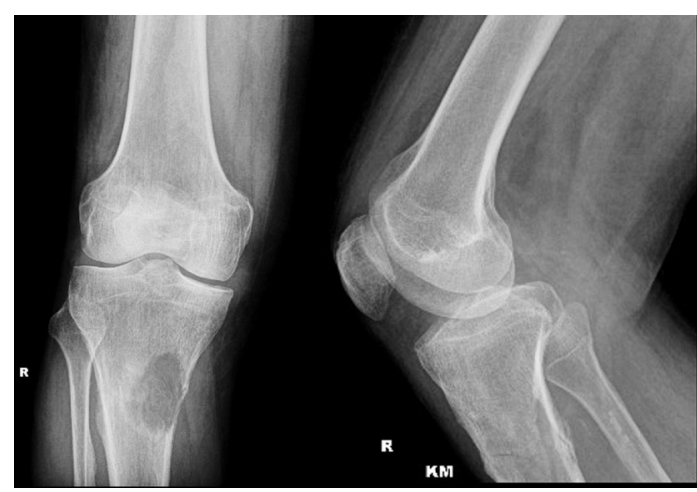

Figure 1 Plain X-ray of the right knee with leg anteroposterior and lateral views showing the lytic lesion in the metadiaphyseal region.

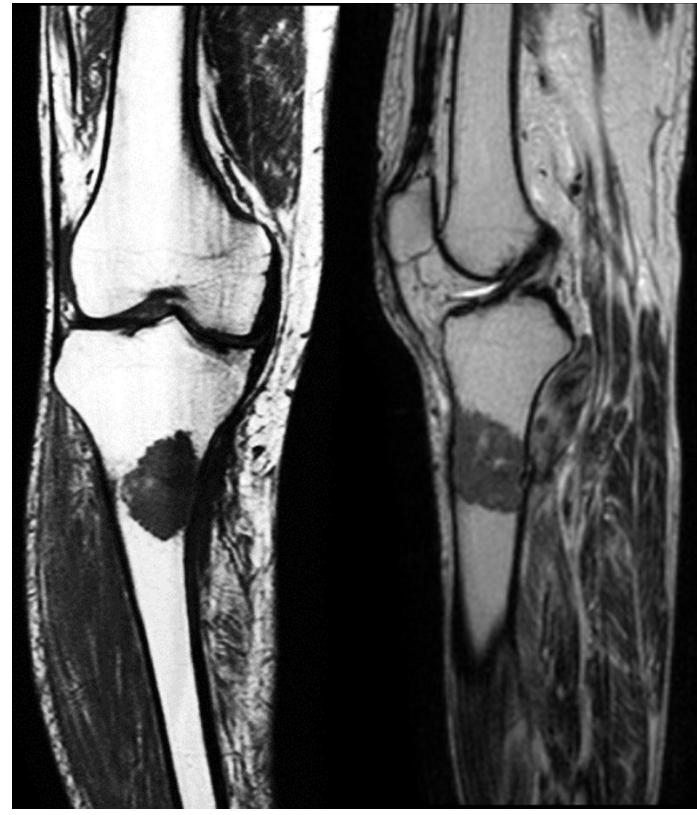

Figure 2 T1-weighted coronal image and T2-weighted sagittal image showing the extent of the lesion.

in tibia so far. $^{2} 3$ To differentiate it from multiple myeloma, an extensive workup consisting of thorough clinical examination, skeletal survey, complete blood picture, renal function tests, serum calcium profile, bone marrow biopsy and serum electrophoresis is necessary. Deranged renal functional tests, altered blood calcium levels, multiple bone lesions and $\mathrm{M}$ band in serum protein electrophoresis favour multiple myeloma diagnosis. In the index case, the

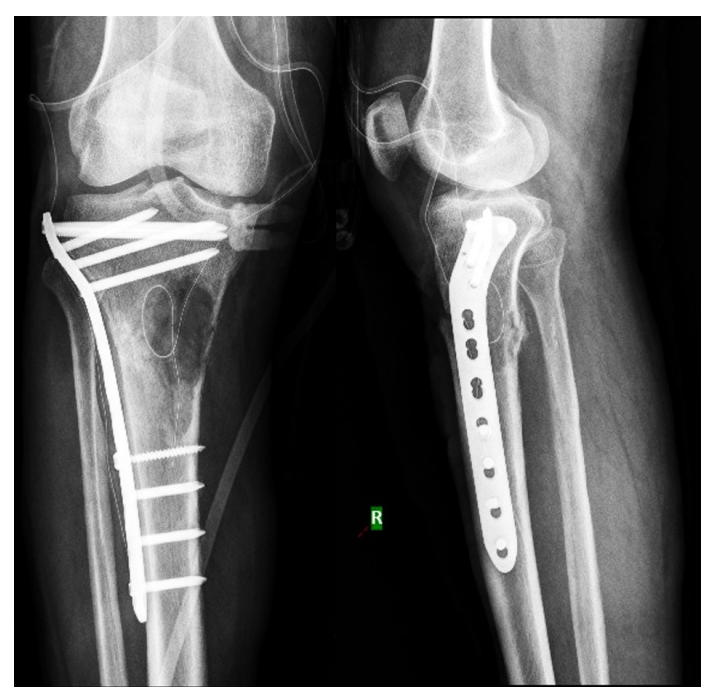

Figure 3 Postoperative plain X-ray of right leg anteroposterior and lateral view showing the prophylactic fixation with $4.5 \mathrm{~mm}$ proximal tibia lateral locking plate. 


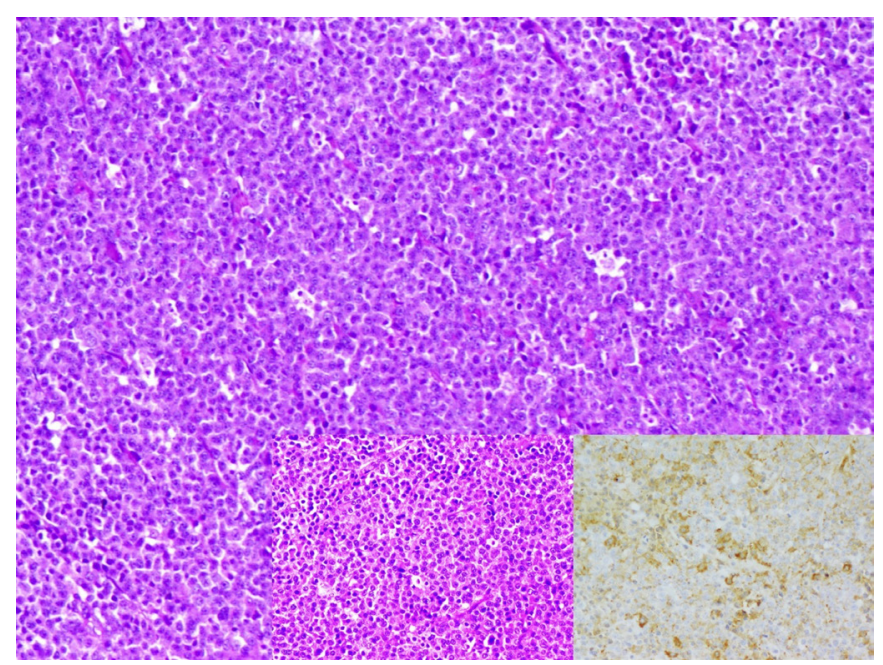

Figure 4 Histopathology (low power, H\&E stain) showing bone and bone marrow infiltration with sheets of tumour cells composed of malignant plasma cells. (Insets: CD138 positive for tumour cells and x40 showing plasma cells having a moderate amount of cytoplasm, regular round to oval nucleus with granular to coarse chromatin.)

lesion appeared as an eccentric solitary lytic lesion in the metadiaphyseal region of the tibia with normal renal and serum calcium

Table 1 Serological parameters, histopathological and microbiological workup of the case

\begin{tabular}{ll}
\hline Investigations & $\begin{array}{l}\text { Reports } \\
\text { (Reference values) }\end{array}$ \\
\hline Haemoglobin & $11.7 \mathrm{~g} / \mathrm{dL}(13-17 \mathrm{~g} / \mathrm{dL})$ \\
\hline TLC & $7.6 \times 10^{9} / \mathrm{L}\left(4-11 \times 10^{9} / \mathrm{L}\right)$ \\
\hline ESR & $4 \mathrm{~mm} / \mathrm{hour}(0-20 \mathrm{~mm} / \mathrm{hour})$ \\
\hline CRP & $4.6 \mathrm{mg} / \mathrm{L}(0-6 \mathrm{mg} / \mathrm{L})$ \\
\hline Glucose (random) & $160 \mathrm{mg} / \mathrm{dL}(60-140 \mathrm{mg} / \mathrm{dL})$ \\
\hline HbA1C & $7.1 \%(<6.5 \%)$ \\
\hline Total serum protein & $7.40 \mathrm{~g} / \mathrm{dL}(6-8 \mathrm{gm} / \mathrm{dL})$ \\
\hline Serum albumin & $4.72 \mathrm{~g} / \mathrm{dL}(3.5-5 \mathrm{gm} / \mathrm{dL})$ \\
\hline Serum calcium & $9.3 \mathrm{mg} / \mathrm{dL}(8.9-10.3 \mathrm{mg} / \mathrm{dL})$ \\
\hline Serum phosphorus & $3 \mathrm{mg} / \mathrm{dL}(2.4-4.7 \mathrm{mg} / \mathrm{dL})$ \\
\hline ALP & $110 \mathrm{U} / \mathrm{L}(50-140 \mathrm{U} / \mathrm{L})$ \\
\hline Serum urea & $20 \mathrm{mg} / \mathrm{dL}(10-40 \mathrm{mg} / \mathrm{dL})$ \\
\hline Serum creatinine & $0.8 \mathrm{mg} / \mathrm{dL}(0.6-1.4 \mathrm{mg} / \mathrm{dL})$ \\
\hline Bence Jones protein (urine) & Negative \\
\hline Culture and sensitivity & No growth \\
\hline PCR (nested) for MTB & Negative \\
\hline Bone marrow aspirate and biopsy & No evidence of Infiltration \\
\hline Serum electrophoresis & No M band seen \\
\hline Immunofixation electrophoresis & Increased lgG kappa, high K/L ratio \\
\hline Tissue biopsy & Sheets of malignant plasma cells seen \\
\hline CD138 & Positive for tumour cells \\
\hline A & \\
\hline
\end{tabular}

ALP, alkaline phosphatase; CRP, C-reactive protein; ESR, erythrocyte sedimentation rate; HbA1c, glycated haemoglobin; MTB, Mycobacterium Tuberculosis; TLC, total leucocyte count.

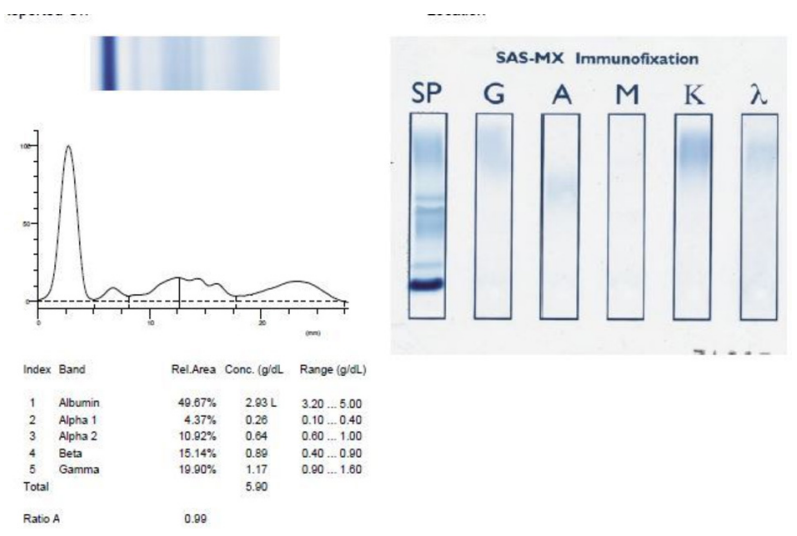

Figure 5 Serum protein electrophoresis and immunofixation electrophoresis report.

profile. Other potential differential diagnoses should include an exhaustive list of lytic bone lesions consisting of aneurysmal bone cyst, giant cell tumour, enchondroma, osteoblastoma, osteosarcoma, adamantinoma, eosinophilic granuloma and Brodie's abscess. Plain and contrast MRI study is useful in differentiating these lesions, where the SBP lesions are typically isointense on T1-weighted images and hyperintense on T2-weighted images and contrast enhanced. Because of a pathological fracture at presentation, plating was performed to provide structural stability. Generally, radiotherapy is the mainstay of treatment for SBP. However, a close follow-up is warranted as it has high potential to convert to multiple myeloma.

\section{Learning points}

- Solitary plasmacytoma involving the long bones, especially tibia, has been rarely reported.

- A high index of clinical suspicion with proper serological, radiological and histopathological evaluation aid in prompt diagnosis and appropriate treatment.

Contributors SM: planning, conduct, reporting, conception and design, acquisition of data and interpretation of data. VP: reporting, conception and design, and interpretation of data. AS: reporting, acquisition of data and interpretation of data. VM: reporting, acquisition of data and interpretation of data, conception and design.

Funding The authors have not declared a specific grant for this research from any funding agency in the public, commercial or not-for-profit sectors.

Competing interests None declared.

Patient consent Obtained.

Provenance and peer review Not commissioned; externally peer reviewed.

\section{REFERENCES}

1 Kilciksiz S, Karakoyun-Celik O, Agaoglu FY, et al. A review for solitary plasmacytoma of bone and extramedullary plasmacytoma. ScientificWorldJournal 2012:2012:1-6.

2 Yamaç K, Fen T, Sancak A, et al. Solitary Plasmacytoma of Tibia in a 29-Year-Old Woman. Turk J Haematol 2002;19:485-7.

3 Kumar P, Sharma SC, Saikia UN, et al. Solitary plasmacytoma of the proximal tibia in an adolescent. Pediatr Blood Cancer 2011;56:158-60. 
Copyright 2018 BMJ Publishing Group. All rights reserved. For permission to reuse any of this content visit http://group.bmj.com/group/rights-licensing/permissions.

BMJ Case Report Fellows may re-use this article for personal use and teaching without any further permission.

Become a Fellow of BMJ Case Reports today and you can:

- Submit as many cases as you like

- Enjoy fast sympathetic peer review and rapid publication of accepted articles

Access all the published articles

- Re-use any of the published material for personal use and teaching without further permission

For information on Institutional Fellowships contact consortiasales@bmjgroup.com

Visit casereports.bmj.com for more articles like this and to become a Fellow 